\title{
Measuring and Managing Macrofinancial Risk and Financial Stability: A New FrameWORK
}

\author{
Dale F. Gray \\ International Monetary Fund \\ Robert C. Merton \\ Harvard University \\ Zvi Bodie \\ Boston University
}

The vulnerability of a national economy to volatility in the global markets for credit, currencies, commodities, and other assets has become a central concern of policymakers. The responsibility for managing these risks at the national level is often given to the central bank. However, the conventional models and analytical tools used by central banks today are ill suited for analyzing these types of risk. This paper proposes a new approach to improve the way central banks can analyze and manage the financial risks of a national economy. It is based on the modern theory and practice of Contingent Claims Analysis (CCA), which is successfully used today at the level of individual banks by managers, investors, and regulators. When applied to the analysis and measurement of credit risk, CCA is commonly called the Merton Model. ${ }^{1}$ The basic analytical tool is the risk-adjusted balance sheet, which shows the sensitivity of the enterprise's assets and liabilities to external shocks. At the national level, the sectors of an economy are viewed as interconnected portfolios of assets, liabilities, and guarantees-some explicit and others implicit. Traditional approaches

We would like to thank Sam Malone, Andrea Maechler, Chris Towe, Mark Swinburne, Matt Jones, John Kiff, Mark Levonian, and Joe Zou (Taconic) for useful discussions and comments on the ideas presented in the paper.

1. See Merton (1973, 1974, 1977, 1992, 1998). Initially developed for valuation of corporate firms, CCA has been adapted to financial institutions and sovereigns.

Financial Stability, Monetary Policy, and Central Banking, edited by Rodrigo A. Alfaro, Santiago, Chile. (c) 2010 Central Bank of Chile. 
have difficulty analyzing how risks can accumulate gradually and then suddenly erupt in a full-blown crisis. The CCA approach is well-suited to capturing such nonlinearities and quantifying the effects of assetliability mismatches within and across institutions. Risk-adjusted CCA balance sheets facilitate simulations and stress testing to evaluate the potential impact of policies to manage systemic risk.

The paper starts with a description of contingent claims analysis and then outlines a simple framework of CCA balance sheets for four key sectors (namely, the sovereign, financial, corporate, and household sectors). It describes how the sectoral CCA balance sheets can be constructed and linked together. Several different types of risk exposures and risk transmission channels are discussed. Finally, the paper shows how the CCA financial risk indicators can be used in stress testing, linked to macroeconomic and monetary policy model.

\section{Contingent Claims Analysis}

A contingent claim is any financial asset whose future payoff depends on the value of another asset. The prototypical contingent claim is an option - the right to buy or sell the underlying asset at a specified exercise price by a certain expiration date. A call is an option to buy; a put is an option to sell. Contingent claims analysis is a generalization of the option pricing theory pioneered by Black and Scholes (1973) and Merton (1973). Since 1973, option pricing methodology has been applied to a wide variety of contingent claims. In this paper we focus on its application to the analysis of credit risk and guarantees against the risk of default.

The contingent claims approach is based on three principles: the values of liabilities are derived from assets; liabilities have different priority (that is, senior and junior claims); and, assets follow a stochastic process. The liabilities consist of senior claims (such as senior debt), subordinated claims (such as subordinated debt), and junior claims (equity or the most junior claim). As total assets decline, the value of risky debt declines and credit spreads on risky debt rise.

Balance sheet risk is the key to understanding credit risk and crisis probabilities. Default happens when assets cannot service debt payments. Uncertain changes in future asset value, relative to promised payments on debt, is the driver of default risk. Figure 1 illustrates the key relationships. The uncertainty in asset value is represented by a probability distribution at time horizon $T$. At the end of the period, the value of assets may be above the promised 
payments, indicating that debt service can be made, or below the promised payments, leading to default. The area below the distribution in panel A of figure 1 is the "actual" probability of default. The assetreturn probability distribution used to value contingent claims is not the "actual" one but the "risk-adjusted" or "risk-neutral" probability distribution, which substitutes the risk-free interest rate for the actual expected return in the distribution. This risk-neutral distribution is the dashed line in panel $\mathrm{B}$, with expected rate of return $r$, the risk-free rate. Thus, the risk-adjusted probability of default calculated using the risk-neutral distribution is larger than the actual probability of default for all assets that have an actual expected return $(\mu)$ greater than the risk-free rate $r$ (that is, a positive risk premium). ${ }^{2}$

The calculations of the actual probability of default is outside the CCA/Merton Model, but it can be combined with an equilibrium model of underlying asset expected returns to produce estimates that are consistent for expected returns on all derivatives, conditional on the expected return on the asset. The reason is that one does not have to know expected returns to use the CCA/Merton Models for the purpose of value or risk calculations.

The value of assets at time $t$ is $A(t)$. The asset return process is $d A / A=\mu_{A} d t+\sigma_{A} \varepsilon \sqrt{t}$, where $\mu_{A}$ is the drift rate or asset return, $\sigma_{A}$ is equal to the standard deviation of the asset return, and $\varepsilon$ is normally distributed, with zero mean and unit variance. The probability distribution at time $T$ is shown in panel A of figure 1 .

Default occurs when assets fall to or below the promised payments, $B_{t}$. The probability of default is the probability that $A_{t} \leq B_{t}$ which is

$$
\begin{aligned}
\operatorname{Prob}\left(A_{t} \leq B_{t}\right) & =\operatorname{Prob}\left\{A_{0} \exp \left[\left(\mu_{A}-\sigma_{A}^{2} / 2\right) t+\sigma_{A} \varepsilon \sqrt{t}\right] \leq B_{t}\right\} \\
& =\operatorname{Prob}\left(\varepsilon \leq-d_{2, \mu}\right) .
\end{aligned}
$$

Since $\varepsilon \sim N(0,1)$, the actual probability of default is $N\left(-d_{2, \mu}\right)$, where

$$
d_{2, \mu}=\frac{\ln \left(A_{0} / B_{t}\right)+\left(\mu_{A}-\sigma_{A}^{2} / 2\right) t}{\sigma_{A} \sqrt{t}} .
$$

$N(\cdot)$ is the cumulative standard normal distribution. 
Figure 1. Asset Value and Probability of Default

A. Asset value

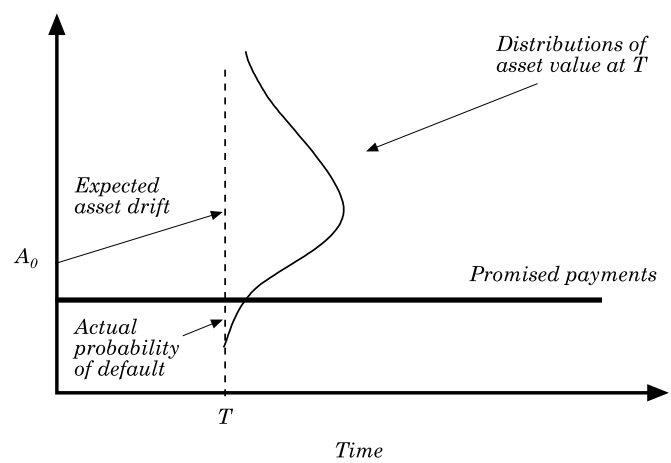

B. Asset value and actual and risk-adjusted probability of default

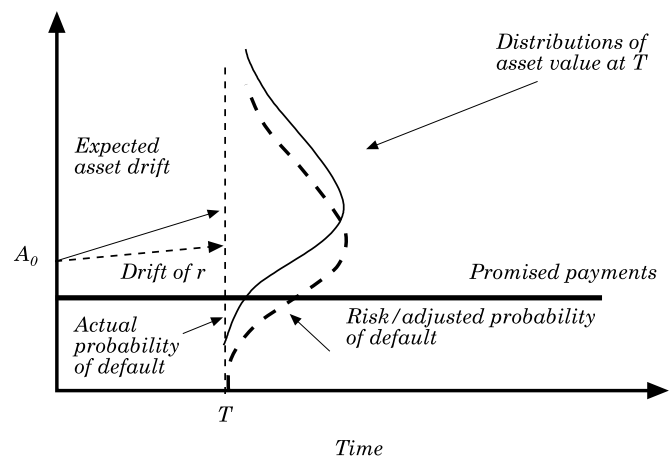

Source: Authors' elaboration; adapted from Gray and Malone (2008).

Shown in panel B of figure 1 is the probability distribution (dashed line) with drift of the risk-free interest rate, $r$. The riskadjusted probability of default is $N\left(-d_{2}\right)$, where

$$
d_{2}=\frac{\ln \left(A_{0} / B_{t}\right)+\left(r-\sigma_{A}^{2} / 2\right) t}{\sigma_{A} \sqrt{t}} .
$$

Box 1 presents the Merton Model equations. (See the appendix for more details, including extensions of the Merton Model.) 


\section{Box 1. Merton Model Equations for Pricing Contingent Claims}

The total market value of assets at any time, $t$, is equal to the market value of the claims on the assets, equity, and risky debt maturing at time $T$ :

Assets $=$ Equity + Risky Debt,

$A(t)=J(t)+D(t)$.

Asset value is stochastic and in the future may decline below the point at which debt payments cannot be made on scheduled dates. The equity can be modeled and calculated as an implicit call option on the assets, with an exercise price equal to the promised payments, $B$, maturing in $T-t$ periods. The risky debt is equivalent in value to default-free debt minus a guarantee against default. This guarantee can be calculated as the value of a put on the assets with an exercise price equal to $B$ :

Risky Debt $=$ Default-Free Debt - Debt Guarantee,

$D(t)=B e^{-r(T-t)}-P(t)$.

We omit the time subscript at $t=0$.

The value of the equity is computed using the Black-Scholes-Merton formula for the value of a call:

$J=A N\left(d_{1}\right)-B e^{-r T} N\left(d_{2}\right)$

and

$$
d_{1}=\frac{\ln \left(\frac{A}{B}\right)+\left(r+\frac{\sigma_{A}^{2}}{2}\right) T}{\sigma_{A} \sqrt{T}} \text { and } d_{2}=d_{1}-\sigma_{A} \sqrt{T},
$$

where $r$ is the risk-free rate, $\sigma_{A}$ is the asset return volatility, and $N(d)$ is the cumulative probability of the standard normal density function below $d$.

The formula for the delta of the put option is $N\left(d_{1}\right)-1$. The yield to maturity on the risky debt, $y$, is defined by

$$
y=\frac{\ln (B / D)}{T},
$$

where $D=B e^{-y T}$ and the credit spread is $s=y-r$.

The risk-neutral or risk-adjusted default probability is $N\left(d_{2}\right)$.

Example: Assuming that $A=\$ 100, \sigma_{A}=0.40$ (40 percent), $B=\$ 75$, $r=0.05(5 \%)$, and $T=1$ (one year), the value of the equity is $\$ 32.37$, the value of risky debt is $\$ 67.63$; the yield to maturity on the risky debt is 10.34 percent, and the credit spread 5.34 percent. The risk adjusted probability of default is 26 percent. 
Financial fragility is intimately related to probability of default. Shocks to flows, prices, or liquidity frequently end up being converted into credit risk in a crisis. Default is hard to handle in traditional macroeconomic models, in part because the assumptions usually exclude the possibility of default. In addition, flow-of-funds accounts and accounting balance sheets cannot provide measures of risk exposure that are forward-looking estimates of losses. CCA is a framework that explicitly includes the probability of default.

\section{Contingent Claim Balance Sheets for Sectors}

We view an economy as a set of interrelated balance sheets with four types of aggregate sectors-corporate, financial, household, and sovereign. The same general principles of contingent claims that apply to the analysis of a single firm can also be applied to an aggregation of firms. The liabilities of a firm, a portfolio of firms in a sector, or the sovereign (that is, the combined government and monetary authorities) can be valued as contingent claims on the assets of the respective firm or sector or sovereign. The corporate sector refers to an aggregation of all nonfinancial firms. Treating the corporate sector as one large firm and the financial sector as one large institution is a very simplified way of looking at the balance sheet, but we start out with this stylized framework to illustrate the risk characteristics of the sector for the purposes of this analysis. Later in the paper, we look at the major financial institutions separately and group the corporate firms into subsectors. The key elements of the balance sheets for the corporate, financial, household, and sovereign sectors are shown in table 1.

\subsection{Economywide Macroeconomic Contingent Claim Balance Sheets and Risk Exposures}

Building on the theory of contingent claims laid out above, the macrofinance valuation identities use put-call parity relationships, which state that the asset value $A$ of each sector is equal to the value of its equity plus the value of its risky debt. ${ }^{3}$ The four primary sectors 


\section{Table 1. Balance Sheets for the Corporate, Financial, Household, and Sovereign Sectors}

\begin{tabular}{lll}
\hline Sector & \multicolumn{1}{c}{ Assets } & \multicolumn{1}{c}{ Liabilities } \\
\hline Corporate & Corporate assets & Debt; equity \\
\hline Financial & $\begin{array}{l}\text { Loans and other assets } \\
\text { (including loans to corporations, } \\
\text { households, and the sovereign); } \\
\text { financial guarantees }\end{array}$ & Debt and deposits; equity \\
\hline Household & $\begin{array}{l}\text { Household assets (including } \\
\text { household income and savings in } \\
\text { the form of deposits and other } \\
\text { financial assets); Net worth in } \\
\text { household real estate assets (on } \\
\text { subsidiary balance sheet, which } \\
\text { includes mortgage debt) }\end{array}$ & $\begin{array}{l}\text { Household net worth (claim } \\
\text { consumption is a dividend } \\
\text { payment out of assets }\end{array}$ \\
& $\begin{array}{l}\text { Foreign currency reserves; net } \\
\text { fiscal asset (present value of }\end{array}$ & $\begin{array}{l}\text { Financial guarantees; } \\
\text { foreign currency debt; base } \\
\text { taxes minus expenditures); other } \\
\text { money; local currency debt }\end{array}$ \\
\hline $\begin{array}{l}\text { Sovereign } \\
\text { (government } \\
\text { and monetary } \\
\text { authorities }\end{array}$ & \begin{tabular}{l} 
public assets \\
\hline
\end{tabular}
\end{tabular}

Source: Authors' elaboration.

of the economy, for the corporate, financial, sovereign, and household balance sheets, are complemented by the foreign sector. The CCA balance sheet equations for each sector $j$ have the sector assets equal to equity (that is, junior claims) plus risky debt. The function $E_{j}$ refers to the period $t$ value of sector $j$ 's equity (that is, the junior claim), which is modeled as an implicit call option. The horizon period is $T$ for the calculation of the implicit option values. Risky debt, $D_{j}$, is equal to the default-free value of the debt, denoted by $\bar{B}\left(\bar{B}_{i} \equiv B_{i} e^{-r T}\right)$, minus the value of the implicit put option, which is denoted by $P_{j}$ (the expected losses associated with the debt). The time horizon $T$ is the same for all sectors for the calculation of the CCA values at each point in time. Using the notation above, the following equations state the put-callparity relationships for the four domestic sectors. For the corporate sector $(C)$, assets, $A_{C}$, equal equity, $E_{C}$, plus the risky debt, $\bar{B}_{C}-P_{C}$ :

$$
A_{C}=E_{C}+\left(\bar{B}_{C}-P_{C}\right)
$$

For the financial sector $(F)$, assets, $A_{F}$, plus contingent financial support from the sovereign, $\alpha P_{F}$, equals equity, $E_{F}$, plus the value of risky debt/deposits, $\bar{B}_{F}-(1-\alpha) P_{F}$ : 
$A_{F}+\alpha P_{F}=E_{F}+\left[\bar{B}_{F}-(1-\alpha) P_{F}\right]$,

where $P_{F}$ is the implicit put option to the financial sector. ${ }^{4}$ The model assumes that the government's contingent liability, or the value of the explicit or implicit sovereign guarantee, is a fraction $\alpha$ of the total $P_{F}$, and the remainder, $(1-\alpha) P_{F}$, is credit risk remaining in the debt and deposits of the financial sector.

For the sovereign, the assets of the sovereign, $A_{S}$, include foreign currency reserves, $R_{M A}$; the net fiscal asset, $A_{G}$ (defined as the present value of taxes and revenues, including seigniorage, minus the present value of government expenditures); and other public assets, $A_{\text {Other }}$. The liabilities of the sovereign include base money, $M_{B M}$, risky local currency debt $\left(\bar{B}_{S L C}-P_{S L C}\right)$, risky foreign currency debt $\left(\bar{B}_{S F X}-P_{S F X}\right)$, and financial guarantees/contingent liabilities, $\alpha P_{F}$ :

$$
A_{S}=R_{M A}+A_{G}+A_{\text {Other }}=M_{B M}+\left(\bar{B}_{S L C}-P_{S L C}\right)+\left(\bar{B}_{S F X}-P_{S F X}\right)+\alpha P_{F} .
$$

For the household sector, the household asset, $A_{H}$, is the sum of the household sector's financial wealth, $A_{F I N}$, the present value of its labor income, $A_{L}$, and equity in real estate, $E_{H, R E}$. The debt of households to banks and nonbanks is frequently tied to homes and real estate. It is therefore practical to have two segregated but linked household CCA balance sheets. The subsidiary balance sheet would have real estate as the primary asset, with related debt on the liability side. ${ }^{5}$ The households' equity in real estate is modeled as real estate assets, $A_{H, R E}$, minus risky household mortgage related debt, $\bar{B}_{H, R E}-P_{H, R E}$ :

$$
\begin{aligned}
A_{H} & =A_{F I N}+A_{L}+E_{H, R E} \\
& =A_{F I N}+A_{L}+\left[A_{H, R E}-\left(\bar{B}_{H, R E}-P_{H, R E}\right)\right] \\
& =E_{H}+c_{H} .
\end{aligned}
$$

The household sector asset, $A_{H}$, is equal to the household net worth, $E_{H}$, plus $c_{H}$ which is consumption modeled as a dividend payment out of the household asset up to time $T$.

4. Merton (1977) was the first to demonstrate that the government's guarantee to banks could be modeled as an implicit put option.

5 . This structure has many variations. Debt could be included on the main household balance sheet, or additional subsidiary balance sheets could be included relating specific debt obligations to related assets. 
The four-sector CCA balance sheets can be integrated into an economywide balance sheet, as shown in table 2 . For each sector, the assets, plus contingent assets (or minus contingent liabilities), minus equity and junior claims, and minus risky debt sum to zero (down the column in table 2). These interlinked economic balance sheets demonstrate the interdependence among sectors, with one sector long a certain implicit option (plus sign) and another sector short the same implicit option (minus sign). For example, the economic balance sheet of the banking sector has assets consisting of corporate loans (default-free debt minus the value of a put option). The banking sector also includes contingent liabilities (implicit put options) from the government as an asset, which is an obligation (short put option) on the government's economic balance sheet. ${ }^{6}$

\section{Table 2. Economywide Contingent Claim Balance Sheet with} Risk Exposures across Sectors (Implicit Put and Call Options)

\begin{tabular}{|c|c|c|c|c|c|}
\hline & Corporate & Households & Financial & Sovereign & Foreign \\
\hline Assets & $A_{C}$ & $\begin{array}{c}A_{F I N}+A_{L} \\
+\left[A_{H, R E}\right. \\
-\left(\bar{B}_{H, R E}\right. \\
\left.\left.-P_{H, R E}\right)\right]\end{array}$ & $A_{F}$ & $\begin{array}{c}R_{M A}+A_{G} \\
+A_{\text {Other }}\end{array}$ & \\
\hline $\begin{array}{l}\text { Contingent assets } \\
\text { and liabilities }\end{array}$ & & & $+\alpha P_{F}$ & $-\alpha P_{F}$ & \\
\hline $\begin{array}{l}\text { Equity/junior and } \\
\text { subordinate claims }\end{array}$ & $-E_{C}$ & $-E_{H}-c_{D}$ & $-E_{F}$ & $\begin{array}{c}-M_{B M}-\bar{B}_{S L C} \\
+P_{S L C}\end{array}$ & \multirow{3}{*}{$\begin{array}{l}\text { Foreign } \\
\text { claims }\end{array}$} \\
\hline Barrier & $-\bar{B}_{C}$ & & $-\bar{B}_{F}$ & $-\bar{B}_{S F X}$ & \\
\hline Expected loss (put) & $+P_{C}$ & & $+\left(1-\alpha_{G}\right) P_{F}$ & $+P_{S F X}$ & \\
\hline Sum & 0 & 0 & 0 & 0 & 0 \\
\hline
\end{tabular}

Source: Authors' elaboration.

The financial assets of the sectors can be separated into claims on foreigners and claims on domestic entities. For simplicity, the detailed cross-holdings by the household sector, financial sector, and foreign sector on the other sectors are not shown in table 2 .

6. Macrofinancial risk models similar to this framework have been calibrated for over 20 countries (although only a few incorporate the household sector). 


\subsection{Interrelationship of Macrofinancial Contingent Claim Balance Sheets, Risk Exposures, and Traditional Macroeconomic Flows}

We now show how the traditional macroeconomic flow-of-funds account can be recovered from the CCA equations when risk goes to zero. When the volatility of assets in the CCA balance sheet equations (table 2) is set to zero, the values of the implicit put options go to zero. ${ }^{7}$ The result is the accounting balance sheet of the sectors. The flow of funds can thus be seen as a special deterministic case of the CCA balance sheet equations when volatility is set to zero and annual changes are calculated. The implicit put options in risky debt and contingent liabilities allow for risk to be transmitted between sectors in the CCA model. Without volatility, the risk transmission between sectors is lost.

The combined accounts-that is, income/flow, mark-to-market balance sheets, and risk exposure measures-comprise the three important sets of interrelated accounts in the economy, which are somewhat similar to the accounts in large modern financial institutions. ${ }^{8}$ Risk managers would find it difficult to analyze the risk exposure of their firm or financial institution by relying solely on the income and cash flow statements, without taking into account (mark-to-market) balance sheets or information on their institution's derivative or option positions. Country risk analysis that relies only on a macroeconomic flow-based approach is deficient in a similar way, given that the traditional analysis does not take into account the volatility of assets.

\subsection{Measuring Implied Asset Value and Volatilities Using Market Prices}

The market value of the assets of corporations, financial institutions, or sovereigns cannot be observed directly. However, the observed prices and volatilities of market-traded securities can be

7. If the volatility of assets goes to zero, then in the put option formula $N\left(-d_{1}\right)=N\left(-d_{2}\right)=0$, which means that the implicit put option values in the sectors go to zero. It is not possible to measure the expected loss and credit risk with asset volatility set to zero. Furthermore, if volatility goes to zero, then $N\left(-d_{1}\right)=N\left(-d_{2}\right)=1$, and the value for the junior claim of the representative sector then reduces to the accounting net worth, equal to deterministic assets minus a measure of the book value of debt. See Gray and Malone (2008) for details.

8. Enterprise risk management is a framework to comprehensively measure and manage risk in firms and financial institutions. Its use has expanded in recent years. 
used to estimate the implied values and volatilities of the underlying assets. ${ }^{9}$ These implied asset values and asset volatilities can be used to calibrate the pricing and risk model of major sectors in the economy. We discuss briefly how this can be done first for firms and financial institutions, then for the sovereign.

\subsubsection{Firms and financial institutions}

Domestic equity markets provide pricing and volatility information for the calculation of implied assets and implied asset volatility in corporations and bank and nonbank financial institutions. The simplest method solves two equations for two unknowns, asset value and asset volatility. Details are shown in the appendix and in Merton (1974) and Crouhy, Galai, and Mark (2000). Moody's KMV has successfully applied its version of the CCA model to measure the implied asset values and volatilities and to calculate expected default frequencies (EDFs) for over 50,000 firms and financial institutions in 55 countries around the world (Crosbie, 1999 and 2001).

For unlisted corporates and banks, the relationship between the accounting information and the risk indicators of companies with traded equity can be used as a guide for mapping the accounting information of companies without traded equity to default probabilities and risk indicators for institutions that do not have traded equity. An example is Moody's RiskCalc for corporate sectors in many countries and for banks in the United States.

\subsubsection{Sovereign}

Since the market value of sovereign assets cannot be observed directly, a similar calibration procedure can be used for the sovereign balance sheet to estimate implied sovereign assets and asset volatility. The prices in the international markets (including the foreign currency market), together with information from domestic market prices, provide the market information for the value and volatility of certain liabilities on the sovereign balance sheet. ${ }^{10}$ If we subtract the financial guarantees from both sides of the sovereign balance sheet in the bottom rows in table 1, the remaining sovereign

9. An implied value refers to an estimate derived from other observed data. Techniques for using implied values are widely practiced in options pricing and financial engineering applications. See Bodie and Merton (2000).

10. See Gray, Merton, and Bodie (2002 and 2006). 
liabilities are structured in a way that is consistent with the CCA framework. On the simplified sovereign balance sheet, the local currency debt of the government, held outside of the monetary authorities, and base money are local currency liabilities, which are modeled as a call option on the sovereign assets with the default barrier derived from the foreign currency debt. A simple two-claim CCA framework is used to calibrate the sovereign balance sheet by calculating implied sovereign assets, $V_{\text {Sovereign }}$, and asset volatility. This calibrated risk-adjusted balance sheet can be used to estimate credit risk in sovereign foreign currency and local currency debt, as well as other risk indicators. These indicators are robust measures of sovereign credit risk. ${ }^{11}$ Scenarios and simulations can be carried out to evaluate the impact of fiscal and debt management policies and the impact of risk transfer onto the sovereign balance sheet.

\subsubsection{Household sector balance sheet}

Modeling household balance sheets using CCA principles is much more difficult than for firms, financial institutions, or sovereigns. Households have no traded equity, so techniques that use equity to imply assets are not applicable. One alternative for constructing the household balance sheet is to use a bottom-up approach. In the household sector, we can use macroeconomic data and information from household surveys to construct measures of the portfolio of household assets directly, for the most part, and try to estimate the volatility of household assets directly. Household balance sheet assets include financial assets (such as pension assets, annuities, mutual funds, and bank deposits) and estimated labor income (that is, the present value of expected labor income) (see Gray and Malone, 2008). For the household subsidiary balance sheet, direct estimation of the real estate prices, volatilities, and debt obligations is likely to be the most practical (but admittedly difficult) approach. Ideally. this analysis should be carried out not for the total household sector, but for households segmented by income groups. ${ }^{12}$

11. Applications to a wide range of countries are described in Gapen and others (2004, 2008) and Gray, Merton, and Bodie (2007). Extensions for modeling the valuation of sovereign local-currency debt are described in Gray and Malone (2008) and Gray and others (2008).

12. It may be very difficult to model households in this way due to data limitations in many countries. CCA balance sheets for households are therefore not as accurate as the corporate or bank or sovereign CCA balance sheet models. 


\subsection{Some Important Extensions and Refinements of CCA Models}

Numerous extensions of the original Merton Model have been developed that relax certain assumptions in the original model. These extensions are described in more detail in the appendix, but two extensions are important to mention here.

First, recent research studies the relationship between the volatility skew implied by equity options and credit default swap (CDS) spreads. Hull, Nelken, and White (2004) establish a relationship between the implied volatility of two equity options, leverage, and implied asset volatility. This approach is, in fact, another way of implementing Merton's model to get spreads and risk-neutral default probabilities directly from the implied volatility of equity options. When the probability distributions derived from the option prices are negatively skewed (left tailed), then the implied underlying asset distribution is also negatively skewed, which results in a higher probability of assets being below the distress barrier and thus in higher spreads (Zou, 2003). In the sovereign CCA application, the probability distributions derived from foreign exchange option prices show that more negatively skewed foreign exchange distributions are associated with higher sovereign credit risk in emerging markets (see Gray, Merton, and Bodie, 2007). The CCA framework is thus able to link information from equity and foreign exchange options to credit risk and spreads. Financial stability reports usually look separately at credit risk indicators, probability distributions from option prices, and associated market sentiment indicators like the VIX. CCA provides a structural framework linking the option price information to skews in implied asset distributions and thus to credit risk.

Second, the Merton Model has been extended to include stochastic interest rates. For example, Shimko, Tejima, and van Deventer (1993) include a Vasicek interest rate term structure model that allows interest rates and the term structure of interest rates to vary. This closed-form model, called the Merton-STV model, is a very useful extension that links the impact of changing interest rate levels, volatilities, and term structures to credit risk in financial institutions and corporations.

\section{Measuring Risk Exposures}

So far, we have discussed how to calculate the value of risky debt, guarantees, and equity using the CCA approach. We now turn to how to measure the risk exposures. The values of the contingent 
claims on the CCA balance sheets contain embedded implicit options that can be used to obtain certain risk measures. These include risk exposures in risky debt, probabilities of default, distance to distress, spreads on debt, the sensitivity of the implicit options to changes in the underlying asset, and other measures. The implicit put option increases nonlinearly as the market value of the sector's assets decline. ${ }^{13}$ The delta measures this nonlinear change in the value of an option per unit change in the value of the underlying asset, as illustrated in figure 2 .

\section{Figure 2. Implicit Put Option Value and Delta ${ }^{a}$}

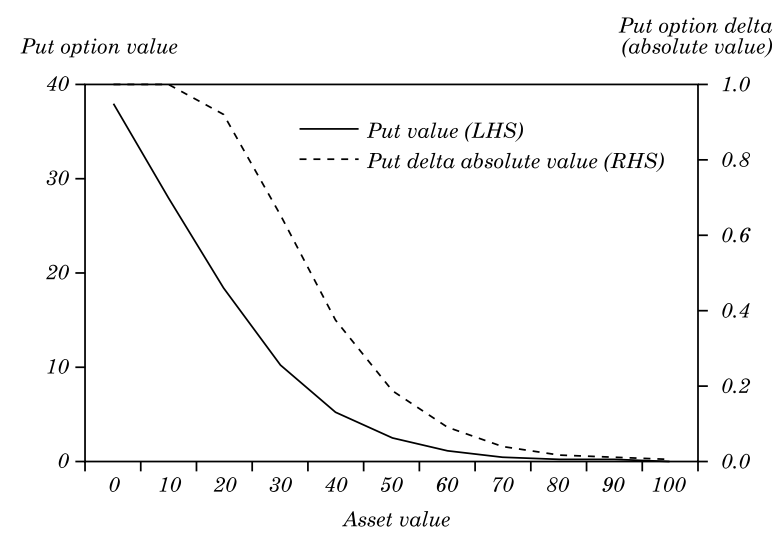

Source: Authors' computation.

a. The strike price is 40 ; asset volatility is 40 percent.

For example, the government's exposure to its guarantee to the banking sector can be measured with the delta of the banking sector implicit put option. There are other important sensitivity measures for risk exposures. The gamma is the change in the delta with respect to the underlying asset. The vega is the sensitivity of the change in the implicit option with respect to a change in asset volatility. These sensitivity measures of risk exposures could provide useful new indicators of the potential for financial instability. 


\subsection{Risk Transmission between Sectors}

The framework described above is versatile and can be used to understand many types of crises and risk shifting that cannot be easily analyzed with other techniques. The risk-transmission patterns can be dampened or magnified depending on the capital structure and linkages. The framework can help identify situations in which volatility gets magnified and negative feedback loops that can trigger severe crises. The patterns of value and default correlation across different asset classes, sectors, and sovereign debt values depend on these structures and links, which are unique to a particular economy. Below are some examples of risk transmission between sectors.

\subsubsection{Risk transmission from the corporate sector to the banking sector}

The corporate sector's financial distress-possibly caused by stock market decline, recession, commodity price drops, or excessive unhedged foreign debt accompanied by currency devaluation-can be transmitted to the financial sector. As the value of the corporate sector's assets declines, so does the value of its debt (and equity), which leads to a decline in bank assets and an increase in banking sector credit risk. The risk transfer can thus be diagramed as follows:

\section{Corporate Sector $\rightarrow$ Banking Sector}

The implicit put option in the banking sector derives its value from banking assets that have embedded put options in risky loans to the borrower. The household sector can similarly transmit risk to the banking sector.

\subsubsection{Risk transmission from the banking sector to the government}

The banking sector's financial distress, such as systemic banking crises or deposit runs, can be transmitted to the government by increasing the value of state guarantees, resulting in the following risk transfer: 
Banking sector distress from nonperforming loans or a deposit run can result in a large increase in the government's implicit guarantee. ${ }^{14}$

\subsubsection{Risk transmission from the government to the banks and feedback}

The government's financial distress or default can transmit risk to the financial system. For example, when the banking sector is holding a significant proportion of government securities, and there is a negative shock to the government financial position, it can have a detrimental impact on the banks. The government's implicit guarantee is also likely to increase. This, in turn, makes the government financial position even worse, which may result in the government's failure to honor its guarantee obligations and cause a collapse of the banking system.

\section{Government $\leftrightarrow$ Banking/Financial System}

This vicious cycle could arise when the lower value of government securities reduces bank assets and raises the implicit financial guarantee, which, in turn, lowers government assets further. A similar process could occur if banks have significant lending denominated in foreign exchange and a weak government position causes a depreciation of the exchange rate: the depreciation worsens the position of the banks and thus raises the implicit guarantee, which then lowers government assets further. This means that the implicit guarantee is higher than what is shown above. In some situations, this vicious cycle can spiral out of control, eventually undermining the government's ability to provide sufficient guarantees to banks and leading to a systemic financial crisis.

\subsubsection{Risk transmission from the pension system to the government}

Financial distress related to pension plans can result in the transmission of risk to the government:

$$
\text { Pension System } \rightarrow \text { Government }
$$


We assume that the pension system is a defined benefit plan that has an implicit government guarantee. A decline in corporate assets would cause the corporate equity value to drop. This, in turn, increases the government guarantee to the pension system and the implicit guarantee to banks. ${ }^{15}$

\subsubsection{Risk transmission from the sovereign to holders of sovereign debt}

Fiscal, banking, and other problems can cause distress for the government, which can transmit risk to holders of government debt denominated in both foreign and local currencies:

\section{Sovereign $\rightarrow$ Sovereign Debt Holders}

Holders of foreign currency debt have a claim on the value of the debt minus the potential credit loss, which is dependent on the level of assets of the sovereign (in foreign currency terms) relative to the foreign currency default barrier. If debt holders demand higher spreads to cover the credit risk in government debt, then the interest rates on government debt could rise, leading to a depreciation. The associated feedback could further worsen the sovereign's financial position.

\subsubsection{Risk transmission from the markets to households and consumption}

Changes in the value of financial assets and real estate owned by households affect the value of household assets and have an impact on consumption:

Financial and Real Estate Markets $\rightarrow$ Household Assets $\rightarrow$ Consumption

The CCA models for the household sector could provide useful insights into household behavior regarding consumption, especially how consumption changes with household asset volatility (and higher moments of the household asset distribution). This is because the CCA captures non-linearities in the value of household debt and in the changes in consumption. 


\subsubsection{Nonlinear risk transmission between sectors through implicit put options}

Risk is transmitted across the sectors and balance sheets through implicit put options in risky debt and guarantees. Risky debt contains an implicit put option. If this risky debt is linked to the asset of another sector (for example, through loans from the financial sector), the risky debt of the second sector (in this case, banks) becomes a function of the implicit put option of the first sector. In other words it is a compound put option. The compound nature of the implicit put options of interlinked sectors creates the potential for highly nonlinear risk transmission. An illustration is provided in box 2 .

The dynamics of the interlinked CCA risk-adjusted balance sheets provide useful insights into the asymmetric nature of value changes and risk transmission in business cycle expansions versus contractions. In a situation of rapid economic growth, asset and equity values on balance sheets trend upward. A stress event somewhere in the system can set off a chain reaction of defaults as the implicit put options are exercised. The compound nature of the implicit put options can cause a sudden sharp decline in the value of risky debt or a sharp increase in implicit guarantees. There is thus an asymmetry in the change in values in the stress or crisis period vis-à-vis the smoother rate of change in the build-up phase of the business cycle.

\section{Box 2. Highly Nonlinear Risk Exposures from Interlinked Sectors}

The risky debt of sector one, $\mathrm{S} 1$, is the default-free value of debt minus an implicit put option, which we assume is the asset of sector two, S2, that is, $\left(\bar{B}_{S 1}-P_{S 1}\right)=A_{S 2}$. In sector two, the assets are equal to equity plus risky debt, $A_{S 2}=E_{S 2}+\left(\bar{B}_{S 2}-P_{S 2}\right)$. If we combine these equations and rearrange, we see that the implicit put option, that is, the present value of expected losses associated with the debt of $\mathrm{S} 2$, is a function of the implicit put option in $\mathrm{S} 1$ :

$$
P_{S 2}=f\left[\left(\bar{B}_{S 1}-P_{S 1}\right), \sigma_{A, S 2}, \bar{B}_{S 2}, r, t\right] .
$$


To illustrate this relationship, we look at bank loans to borrowers whose risky debt can be modeled as the default-free value of the loan minus an implicit put option (derived from the borrower's asset level, asset volatility, and leverage). The bank's risk exposure derives from a compound put option, since it depends on the bank assets whose value depends on the borrower's risky debt. This compound option can lead to highly nonlinear risk exposures. For example, suppose a bank's assets consist entirely of risky debt to a corporate sector with promised payments of 100. Figure B1 illustrates how the value of the bank's implicit put option increases as (i) the corporate sector debt-to asset-ratio increases; and (ii) the volatility of the corporate assets increases.

\section{Figure B1. Bank Expected Losses (Implicit Put Option) versus Corporate Sector Debt-to-Asset Ratio for High and Low Volatility of Corporate Assets}

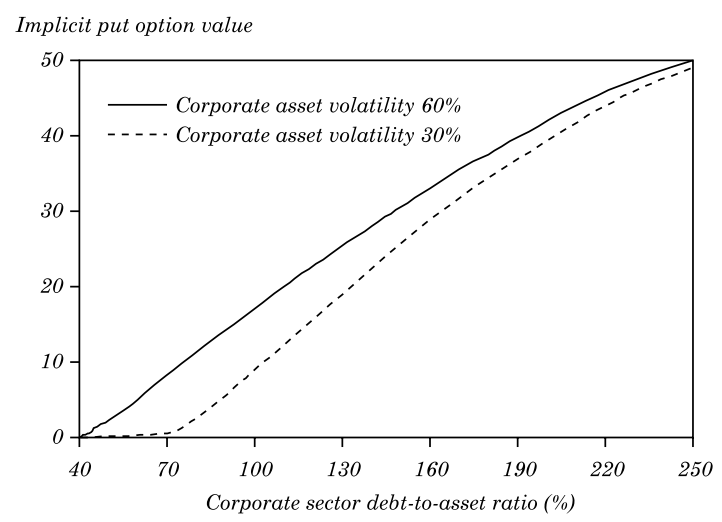

Source: Authors' computation.

This means that the (absolute value) of the delta of the bank's implicit put option is high when the volatility of corporate assets is high, and it is high even when the corporate debt-to-asset ratio is low. While this is just a stylized example, the nonlinear nature of the implicit put options was clearly evident in the Thailand crisis. There were high levels of foreign-currency-denominated debt in the corporate sector in Thailand in 1996. In 1997, devaluation, combined with a decline in the stock market and increased volatility, led to widespread bankruptcies, which transmitted risk to bank balance sheets and to the government via the implicit guarantee. The implicit government guarantee to the banking system was 3 percent of GDP in 1996 and increased to over 35 percent of GDP following the 1997 devaluation (Gray, 2001). 


\subsection{Balance Sheet Risk Framework for Stress Testing, Scenario, and Simulation Analysis}

The economywide CCA model can be used with scenario, simulation, and stress-testing analysis. There are different levels of sectoral aggregation, which range from the simple four sector model described here to a model with several corporate subsectors, a disaggregation of the household sector by income groups, and several financial sector divisions. The level of aggregation depends on practical issues related to data availability, data reliability, and the goals of the analysis. By simulating shocks to key variables, one can see how the CCA risk indicators and implicit put and call options are affected in other sectors.

The structure and aggregation of CCA models can be designed to analyze risk in major financial institutions for financial stability analysis. Since distress in one major institution can affect systemic stability, it makes sense to try to model the risk for major institutions individually and group smaller financial institutions to keep the model size manageable.

There are different ways to link these financial institutions to other sectors and to macroeconomic variables and use the model for stress testing. Some examples are described below.

\subsubsection{Financial stability stress testing with CCA, factor, and macroeconomic models}

First, a CCA model is calibrated for each major financial institution (or groups of institutions) using equity market information, and the time series of implied assets and risk indicators is calculated (calibration can be done using the Merton Model, Hull's implementation of the Merton Model, or another CCA model). The time pattern of asset returns of each financial institution (or of the risk indicators) can be used as the dependent variable in a factor model. Key factors driving these asset returns could include gross domestic product (GDP), domestic and foreign interest rates, the exchange rate, domestic and foreign equity indices, and so on. A separate macroeconomic scenario generating model, such as a macroeconomic VAR or GVAR model, ${ }^{16}$ could then be used to test the impact of the scenarios on the key factors, which feed into the

16. Hoggarth, Sorensen, and Zicchino (2005) discuss the use of VAR models for stress testing. Pesaran, Schuermann, and Wiener (2004) and Castrén, Dees, and Zaher (2007) use GVAR models to generate scenarios for credit risk analysis. 
financial institution's assets. This, in turn, affects the credit risk indicators and the value of equity capital. ${ }^{17}$

This stress-testing process can be summarized in four steps. Macroeconomic scenarios are generated with a VAR, GVAR model, or other model (step 1). ${ }^{18}$ The scenarios are then used in the factor model for the bank's assets (step 2). The factor model provides the basis for estimating the impact of the scenarios on the bank's assets and its credit risk (implicit put option) (step 3) and on the bank's equity capital (step 4$)$.

\subsubsection{Banking stability stress testing with links to the corporate and household sectors}

Given sufficient data on corporate and household sector balance sheets, the previous approach can be modified to first calibrate the CCA models for key financial institutions (as before) and calibrate the corporate and household sector CCA balance sheets. The next step is to use data on banks' exposure to various subsectors to provide the links between bank assets and the risky debt obligations of the borrowers. Risk is transmitted by the changing value of the implicit put options in the borrower's risky debt. A factor model could be estimated for the time series of corporate and household sector assets returns and used in conjunction with macroeconomic scenarios similar to the approach described earlier. ${ }^{19}$

\subsubsection{Stress testing and capital adequacy assessment using CCA models of financial institutions}

One major goal of financial sector stress testing is to assess the capital adequacy of various institutions under different potential shocks. Shocks to financial institution assets and asset volatility or to interest rates and other parameters can be used in the CCA model to measure the impact on capital adequacy. An advantage of using CCA models for financial institutions is that the capital adequacy can be related to asset level, asset volatility, and default probability on

17. The model used by Gray and Walsh (2008) is similar to this approach. See also Gray and Jones (2006).

18. The structural CCA model is a useful framework for understanding the comovements of assets, equity, credit risk, and key volatility measures. It could provide useful insights for structuring VAR models and designing shocks or innovations in those models.

19. Van den End and Tabbae (2005) use CCA balance sheet models and suggest links to factor models, as do Gapen and others (2004). 
the institution's liabilities and other factors. Van Deventer and Imai (1997, 2003) and Belmont (2004) extend this method of calculating capital adequacy to include interest rates, interest rate volatility, and the correlation of asset returns with interest rates, using the Merton-STV model.

The financial stress tests commonly used by central banks and banking supervisors incorporate various models to measure the change in the expected default probability of the obligors, usually representative corporations or corporate subsectors. The default probabilities are then used with estimates of exposure and loss given default in a model of bank credit losses (such as Credit Risk Plus) to estimate the impact on economic capital. ${ }^{20}$ Calibrated CCA models of financial institutions can be used to estimate capital adequacy without the need for detailed data on default probabilities or loss given default of obligors. As pointed out by van Deventer and Imai, "In the capital allocation [using the Merton-STV model], note that we didn't use the probability of default or the loss given default in allocating capital. We don't need to, because the probability of default and loss given default are both implied by the STV model and the value of asset volatility and interest rate and correlation" (van Deventer and Imai, 2003, p. 221). This makes CCA a potentially useful tool when detailed data on obligor exposures, default probabilities, or loss given default are not available.

\subsection{Integrating Financial Risk Models and Indicators with Macroeconomic Models}

Even state-of-the-art macroeconomic models generally leave out credit risk and the market risk of the claims held in agents' financial portfolios. This omission can be serious, because risk affects valuation, and changes in the valuation of agents' claims, and thus of their net worth, affects their decisions to spend, save, and invest. Recent work has begun to address the linkage of macroeconomic and financial stability models. ${ }^{21}$

20. See Sorge (2004). Castrén, Dees, and Zaher (2007) at the European Central Bank use the Moody's KMV median default probability for various corporate sectors with a vector autoregression (VAR) or global VAR. See also Pesaran, Schuermann, and Wiener (2004) and Alves (2005).

21. See Bardsen, Lindquist, and Tsomocos (2006), Goodhart, Sunirand, and Tsomocos (2004, 2006a, 2006b), Tsomocos (2003), Haldane, Hall, and Pezzini (2007), Swinburne (2007), and IMF (2007). 
To understand the interaction of balance sheet risk and the macroeconomy, a promising area of future research is the integration of the financial risk analytic models and indicators with traditional macroeconomic models. Such integrated models need to address the different mathematical nature of macroeconomic models and finance models. Macroeconomic models are primarily stock-flow models in discrete time and are usually geared to forecasting the mean of macroeconomic variables. Financial risk analytics, on the other hand, focus on the probability that assets, following a random walk, will fall below a certain threshold or default barrier, such that volatility (the second moment) rather than the mean (first moment) is the critical element in risk analysis. The CCA framework centers on volatile assets relative to a distress barrier, using option pricing concepts to calculate credit risk indicators. While there can be different levels of aggregation of the CCA balance sheets, whatever level of aggregation is chosen, the time pattern of the following could be calculated and used with macroeconomic models:

-Time series of CCA balance sheet components (namely, assets, asset volatility, distress barriers, and implicit put and call options) and sensitivity measures (such as delta and vega);

-Time series of CCA-derived credit risk indicators (including distance to distress, estimated default probability, and CCA credit spreads) (see box 3 for ways to aggregate credit risk indicators); and

- Time series of market indicators such as observed CDS and bond spreads or market risk appetite indicators (for example, VIX).

These financial risk analytic measures can be related to the time pattern of macroeconomic variables using econometric techniques to study leads, lags, or contemporaneous correlation. Various channels could be investigated using econometrics. For example, the channel from GDP to corporate and household risk indicators and then to financial sector risk indicators could be modeled. The reverse channel from the financial sector (balance sheets and risk indicators) to the corporate and household sector balance sheet components and to risk indicators, and the relationship to GDP over the economic cycle, could similarly be investigated. ${ }^{22}$

22. The dynamics of corporate and household borrowing levels are directly related to distress barriers in the CCA model. 


\section{Box 3. Aggregation of Credit Risk Indicators (CRIs)}

The CCA credit risk indicators of a portfolio of individual financial institutions (or corporate firms) must be aggregated to provide a tractable measure of system risk for use with macroeconomic models and for financial stability analysis. There are several ways to measure the system risk by aggregating the risk indicators of individual banks or institutions.

-Weight the individual default probabilities (that is, the EDFs from Moody's KMV or other default probability estimate) by the implied assets of each bank or financial institution to get a system risk indicator.

-Weight the distance to distress for each institution by the implied assets of each bank or financial institution to get a system risk indicator.

-Use the median EDF for the subsector or group, for example, as calculated by Moody's KMV.

- Sum the implicit put options of a portfolio of institutions to calculate the system expected loss for a given horizon.

-Calculate an Nth-to-default indicator: the time pattern of default risk indicators for a portfolio of individual financial institutions can be used to understand the default correlations and get a credit risk indicator that is the probability of $N$ defaults over a specific horizon.

-Calculate the joint distribution of default probabilities in a portfolio of financial institutions, such as the joint probability modeled with the portfolio multivariate density developed by Segoviano (2006) and Segoviano, Goodhart, and Hofmann (2006).

\subsection{Financial Risk Analytic Indicators and Monetary Policy Models}

Financial stability models and monetary stability models, by their nature, are very different frameworks. There is keen interest in relating these two types of analysis, but no consensus on how it can be done. The primary tool for macroeconomic management is the interest rates set by the central bank. Simple model-based monetary policy models are widely used by central banks to understand macroeconomic and interest rate relationships. ${ }^{23} \mathrm{~A}$ simple four module monetary policy model of this type consists of an equation for the GDP output gap, an equation for inflation, an equation for the exchange rate and real interest rates, and a Taylor rule for setting the domestic policy

23. Berg, Karam, and Laxton (2006a, 2006b) provide a good summary. 
rate. The domestic policy rate is a short-term interest rate set by the central bank, such as the Federal funds rate in the United States.

Since the economy and interest rates affect financial sector credit risk, and the financial sector affects the economy, an important issue is whether credit risk indicators (or CRIs, described in box 3) should be included in monetary policy models and, if so, how. Including an aggregate credit risk indicator in the GDP gap equation and testing whether or not the coefficient is an important first step toward a better understanding of how financial sector credit risk affects GDP. The next step could be to add a fifth equation relating the CRIs to GDP and interest rates (possibly drawing on analysis from the previous section relating financial risk indicators to macroeconomic variables).

Past data could be used to include the CRI in the policy rate reaction function, to examine whether financial stability was taken into account when setting interest rates in the past. A variation of this approach is being investigated in the research department of the Central Bank of Chile. ${ }^{24}$ The approach taken in the Central Bank of Chile is to first estimate the distance to distress for the banking system (each individual bank's distance to distress, from a CCA model that is weighted by bank implied assets). The banking system's distance to distress is included in the GDP gap equation and in the policy rate reaction function. The model parameters are then estimated using historical data, including the distance-to-distress indicator. This approach can be used to examine the tradeoffs between GDP, inflation, and the banking system's distance to distress. ${ }^{25}$

Outputs of the sovereign CCA model include an estimate of the risk premium on government local currency debt, which is embedded in the nominal interest rate. This, in turn, affects the exchange rate, which is part of the GDP gap and inflation equations (the first and second equations in the simple monetary policy model). This issue is important for certain emerging market countries (such as Brazil and Turkey). ${ }^{26}$ These are promising areas for further research. ${ }^{27}$

24. See Gray, García, Luna, and Restrepo (in this volume).

25. A related issue is whether an indicator of market risk appetite such as the VIX should be included in monetary policy models along with the credit risk indicator. This could help estimate the impact of the credit risk indicator on the GDP gap, adjusted for changes in risk appetite.

26. See Gray and Malone (2008) and Favero and Giavazzi (2003).

27 . Other interesting routes for linking risk analytics more closely with macroeconomic models include incorporating default risk and a risk premium into the Mundell-Fleming model to separate out the effects of changes in interest rates due to changes in the market for liquidity and changes in interest rates due to changes in the risk premium on debt (see Gray and Malone, 2008). 
A final point involves the feedback of monetary policy and changes in interest rates on the CCA balance sheet values and risk indicators. CCA models that incorporate changes in interest rates (such as the Merton-STV model or the factor model for asset return with interest rates as one factor) can be used to estimate the second round effects on the credit risk of financial institutions in response to changes in interest rates.

\section{Conclusions}

This paper proposes a new approach to improve the way central banks analyze and manage the financial risks of a national economy. It is based on the modern theory and practice of contingent claims analysis (CCA), which is successfully used today at the level of individual banks by managers, investors, and regulators. The basic analytical tool is the risk-adjusted balance sheet, which shows the sensitivity of the enterprise's assets and liabilities to external shocks. The sectors of an economy are viewed as interconnected portfolios of assets, liabilities, and guarantees-some explicit and others implicit. The CCA approach is well-suited to capturing such nonlinearities and to quantifying the effects of asset-liability mismatches within and across institutions. Risk-adjusted CCA balance sheets facilitate simulations and stress testing to evaluate the potential impact of policies to manage systemic risk. The time pattern of CCA balance sheet components, risk indicators, and sensitivity parameters can be integrated with macroeconomic models. Finally, the paper explored the inclusion of financial system risk indicators and other financial risk parameters in simple monetary policy models. 
ApPENDIX

This appendix provides details on estimating implied assets and asset volatility, and extensions of the Merton Model.

\section{A1. Calculating Implied Assets and Implied Asset Volatility}

The value of assets is unobservable, but it can be implied using CCA. In the Merton Model for firms, banks and nonbank financial institutions with traded equity use equity, $J$, equity volatility, $\sigma_{j}$, and the distress barrier in the following two equations to solve for the two unknowns $A$, asset value, and $\sigma_{A}$, asset volatility (see Crouhy, Galai, and Mark, 2000).

$J=A_{0} N\left(d_{1}\right)-\bar{B} N\left(d_{2}\right)$

and

$J \sigma_{J}=A \sigma_{A} N\left(d_{1}\right)$.

\section{A2. Extensions of the Merton Model}

Numerous extensions of the original Merton Model have been developed that relax certain assumptions in the original model. Restrictions of the model include the assumptions that: (i) default can occur only at the maturity date of the debt; (ii) there is a fixed default barrier; (iii) there is a constant risk-free rate; and (iv) asset volatility is constant. Cossin and Pirotte (2001) provide a good summary of extensions of the Merton Model. Black and Cox (1976) extend the Merton Model to relax the assumptions (i) and (ii) above by introducing a first-passage-time model where default can occur prior to the maturity of the debt if the asset falls below a specified barrier function for the first time.

Although the strict theoretical condition in the Merton Model for default is that the value of assets is less than the required payments due on the debt, in the real world, default typically occurs at much higher asset values, either because of a material breach of a debt covenant or because assets cannot be sold to meet the payments (so-called inadequate liquidity) or because the sovereign decides 
to default and induce a debt renegotiation rather than sell assets. To capture these real-world conditions for default in the model, we specify a market value of total assets at which default occurs. We call this level of assets that trigger default the distress barrier. This barrier can be viewed as the present value of the promised payments discounted at the risk-free rate. The approach used in the KMV model sets the barrier level equal to the sum of the book value of short-term debt, promised interest payments for the next 12 months, and half of long-term debt (see Crouhy, Galai, and Mark, 2000; Crosbie, 1999, 2001).

In the 1990s, the KMV model was based the Vasicek-Kealhofer (VK) model, which has multiple layers of liabilities and several confidential features. Moody's KMV's expected default frequency (EDF) credit measure is calculated using an iterative procedure to solve for the asset volatility. This distance to distress was then mapped to actual default probabilities using a database of detailed real-world default probabilities for many firms. The Moody's KMV distance to distress and the cumulative expected default probabilities (CEDF) are calculated as follows:

$$
D D_{K M V}=f\left[\frac{\ln \left(A_{0} / B_{t}\right)+\left(\mu_{A}-\sigma_{A}^{2} / 2\right) t}{\sigma_{A} \sqrt{t}}\right]
$$

and

$$
C E D F_{t}=f\left[D D_{K M V}(t)\right] .
$$

This definition of $D D_{K M V}$ includes the real drift of the asset, $\mu_{A}$, whereas the distance to distress from the Merton approach has $r$ for the asset drift. Since Moody's KMV estimates the actual default probabilities, the risk-neutral default probabilities are calculated from the correlation of the implied asset with the market, the market Sharpe Ratio, and time horizon.

The CreditGrades (2002) model includes a diffusion of a firm's assets and a first-passage-time default with a stochastic default barrier. The model was modified to incorporate equity derivatives (Stamicar and Finger, 2005). Hull, Nelken, and White (2004) study the relationship between the volatility skew implied by equity options and CDS spreads. They establish a relationship between implied volatility of two equity options, leverage, and asset volatility. This approach is, in fact, another way of implementing Merton's model to 
get spreads and risk-neutral default probabilities directly from the implied volatility of equity options. Zou (2003) discusses a similar approach using several equity options.

The Merton Model has been extended to include stochastic interest rates, as well. Shimko, Tejima, and van Deventer (1993) include a Vasicek interest rate term structure model that relaxes assumption (iii) above, allowing the risk-free interest rate to change and including the correlation of asset return with the interest rate. There are two stochastic factors, the asset and the interest rate. This closed-form model, which is frequently called the STV model, is a very useful extension because it includes the impact of changing interest rate term structures. Longstaff and Schwartz (1995) take the Black and Cox (1976) model and add in stochastic interest rates, similar to the way the STV model includes interest rates. 


\section{REFERENCES}

Alves, I. 2005. "Sectoral Fragility: Factors and Dynamics." BIS papers 22: 450-80. Basel: Bank for International Settlements.

Bardsen, G., K.G. Lindquist, and D.P. Tsomocos. 2006. "Evaluation of Macroeconomic Models for Financial Stability Analysis." Working paper 2006/01. Oslo: Central Bank of Norway, Financial Markets Department.

Belmont, D. 2004. Value Added Risk Management in Financial Institutions. Hoboken, N.J.: John Wiley and Sons.

Berg, A., P. Karam, and D. Laxton. 2006a. "A Practical Model-Based Approach to Monetary and Policy Analysis: How-to Guide." Working paper 06/81. Washington: International Monetary Fund.

. 2006b. "A Practical Model-Based Approach to Monetary and Policy Analysis: Overview.” Working paper 06/80. Washington: International Monetary Fund.

Bernanke, B.S., M. Gertler, and S. Gilchrist. 1999. "The Financial Accelerator in a Quantitative Business Cycle Framework." In Handbook of Macroeconomics, vol. 1, edited by J.B. Taylor and M. Woodford, pp. 1341-93. Amsterdam: Elsevier Science.

Black, F. and J. Cox. 1976. "Valuing Corporate Securities: Some Effects of Bond Indenture Provisions." Journal of Finance 31(2): 351-67.

Black, F. and M. Scholes. 1973. "The Pricing of Options and Corporate Liabilities." Journal of Political Economy 81(3): 637-54.

Bodie, Z. 2006. "On Asset-Liability Matching and Federal Deposit and Pension Insurance." Federal Reserve Bank of St. Louis Review (July): 323-30.

Bodie, Z. and R.C. Merton. 2000. Finance. Upper Saddle River, N.J.: Prentice Hall.

Castrén, O., S. Dees, and F. Zaher. 2007. "How Do Global Macro-Financial Shocks Affect Corporate Sector Expected Default Frequencies in the Euro Area?" Frankfurt: European Central Bank.

Cossin, D. and H. Pirotte. 2001. Advanced Credit Risk Analysis. Hoboken, N.J.: John Wiley and Sons.

CreditGrades. 2002. "CreditGrades Technical Document." New York: RiskMetrics Group.

Crosbie, P.J. 1999. "Modeling Default Risk." San Francisco, Calif.: KMV Corporation.

_ 2001. "Modeling Default Risk." San Francisco, Calif.: KMV Corporation. 
Crouhy, M., D. Galai, and R. Mark. 2000. Risk Management. New York: McGraw Hill.

Draghi, M., F. Giavazzi, and R.C. Merton. 2003. Transparency, Risk Management, and International Financial Fragility, vol. 4. Geneva Reports on the World Economy. Geneva: International Center for Monetary and Banking Studies.

Favero, C. and F. Giavazzi. 2003. "Monetary Policy When Debt and Default Risk Are High: Lessons from Brazil." Seminar paper. London School of Economics, Centre for Economic Performance. Available online at http://cep.lse.ac.uk/seminarpapers/22-05-03GIA.pdf.

Gapen, M.T., D.F. Gray, C.H. Lim, and Y. Xiao. 2004. "The Contingent Claims Approach to Corporate Vulnerability Analysis: Estimating Default Risk and Economy-wide Risk Transfer." Working paper 04/121 Washington: International Monetary Fund.

Contingent Claims." IMF Staff Papers 55(1): 109-48.

Goodhart, C.A.E., P. Sunirand, and D.P. Tsomocos. 2004. "A Model to Analyse Financial Fragility: Applications." Journal of Financial Stability 1(1): 1-30.

. 2006a. "A Model to Analyse Financial Fragility." Economic Theory 27(1): 107-42.

- 2006b. "A Time Series Analysis of Financial Fragility in the

U.K. Banking System.” Annals of Finance 2(1): 1-21.

Gray, D.F. 2001. "Macro Financial Risk Country Report: Thailand, MFRisk and Macro Financial Risk Framework." MFRisk document.

Gray, D.F. and M. Jones. 2006. "Measuring Sovereign and Banking Risk in Indonesia: An Application of the Contingent Claims Approach." In Indonesia: Selected Issues Paper, country report 06/318, chap. 3. Washington: International Monetary Fund.

Gray, D.F., C.H. Lim, E. Loukoianova, and S. Malone. 2008. "A Risk-

Based Debt Sustainability Framework: Incorporating Balance Sheets and Uncertainty." Working paper 08/40. Washington: International Monetary Fund.

Gray, D.F. and S. Malone. 2008. Macrofinancial Risk Analysis. Hoboken, N.J.: John Wiley and Sons.

Gray, D.F., R.C. Merton, and Z. Bodie. 2002. "A New Framework for Analyzing and Managing Macrofinancial Risks." Paper prepared for the Conference on Finance and the Macroeconomy. New York University, 11-12 October. 
2006. "A New Framework for Analyzing and Managing Macrofinancial Risks of an Economy." Working paper 12637. Cambridge, Mass.: National Bureau of Economic Research.

- 2007. "Contingent Claims Approach to Measuring and Managing Sovereign Credit Risk." Journal of Investment Management 5(4): 1-24.

Gray, D. F. and J. Walsh. 2008. "Factor Model for Stress Testing with a Contingent Claims Model of the Chilean Banking System." Working paper 08/89. Washington: International Monetary Fund.

Haldane, A., S. Hall, and S. Pezzini. 2007. "A New Approach to Assessing Risks to Financial System Stability.” Financial stability paper 2. London: Bank of England.

Hoggarth, G., S. Sorensen, and L. Zicchino. 2005. "Stress tests of U.K. banks using a VAR approach.” Working paper 282. London: Bank of England.

Hull, J., I. Nelken, and A. White. 2004. "Merton's Model, Credit Risk, and Volatility Skews." Journal of Credit Risk 1(1): 3-28.

IMF (International Monetary Fund). 2007. Global Financial Stability Report: Financial Market Turbulence Causes, Consequences, and Policies. Washington.

Longstaff, F. and E.S. Schwartz. 1995. "A Simple Approach to Valuing Risky Fixed and Floating Rate Debt." Journal of Finance 50(3): 789-819.

Merton, R.C. 1973. "Theory of Rational Option Pricing." Bell Journal of Economics 4(1): 141-83. Reprinted in Continuous-Time Finance, chap. 8, 1992, Oxford: Basil Blackwell.

1974. "On the Pricing of Corporate Debt: The Risk Structure of Interest Rates." Journal of Finance 29(2): 449-70. Reprinted in Continuous-Time Finance, chap. 12, 1992, Oxford: Basil Blackwell.

. 1977. "An Analytic Derivation of the Cost of Deposit Insurance and Loan Guarantees: An Application of Modern Option Pricing Theory." Journal of Banking and Finance 1(1): 3-11. Reprinted in Continuous-Time Finance, chap. 19, 1992, Oxford: Basil Blackwell.

-1992. Continuous-Time Finance. Oxford: Basil Blackwell. . 1998. "Applications of Option-Pricing Theory: Twenty-Five Years Later." Les Prix Nobel 1997. Stockholm: Nobel Foundation. Reprinted in American Economic Review 88(3): 323-49.

Merton, R.C. and Z. Bodie. 1992. "On the Management of Financial Guarantees.” Financial Management 21(4): 87-109. 
Pesaran, M., T. Schuermann, and S. Wiener. 2004. "Modelling Regional Interdependencies Using a Global Error-Correcting Macroeconometric Model." Journal of Business and Econmic Statistics 22 (April): 129-62.

Segoviano, M.A. 2006. "Portfolio Credit Risk and Macroeconomic Shocks: Applications to Stress Testing under Data-Restricted Environments." Working paper 06/283. Washington: International Monetary Fund.

Segoviano, M.A., C.A.E. Goodhart, and B. Hofmann. 2006. "Default, Credit Growth, and Asset Prices." Working paper 06/223. Washington: International Monetary Fund.

Shimko, D., N. Tejima, and D. van Deventer. 1993. "The Pricing of Risky Debt When Interest Rates Are Stochastic." Journal of Fixed Income 3(2): 58-65.

Sorge, M. 2004. "Stress Testing Financial Systems: An Overview of Current Methodologies." Working paper 165. Basel: Bank for International Settlements.

Stamicar, R. and C. Finger. 2005. "Incorporating Equity Options into the CreditGrades Model." New York: RiskMetrics Group.

Swinburne, M. 2007. "The IMF's Experience with Macro Stress Testing." Paper prepared for the High-Level Conference on Simulating Financial Instability. European Central Bank, Frankfurt, 12-13 July.

Tsomocos, D.P. 2003. 'Equilibrium Analysis, Banking, and Financial Instability." Journal of Mathematical Economics 39(5-6): 61955 .

Van den End, W. and M. Tabbae. 2005. "Measuring Financial Stability: Applying the MFRisk Model to the Netherlands." Working paper 30. Amsterdam: Netherlands Central Bank.

Van Deventer, D. and K. Imai. 1997. Financial Risk Analytics. New York: McGraw-Hill.

. 2003. Credit Risk Models and the Basel Accords. Hoboken, N.J.: John Wiley and Sons.

Zou, J. 2003. "The Relationship between Credit Default Probability and Equity Options Volatility Surface." Paper presented at the Ninth Annual RISK USA Conference. Risk Magazine, Boston, June. 